\title{
Recovery After the Covid-19 Pandemic: The Case of Peruvian Tourism
}

\author{
Jorge Torres Zorrilla \\ Department of Economics, Faculty of Economics, Business and Finance, Universidad San Ignacio Loyola, Lima, Peru
}

\section{Email address:}

jotorres@pucp.edu.pe

\section{To cite this article:}

Jorge Torres Zorrilla. Recovery After the Covid-19 Pandemic: The Case of Peruvian Tourism. International Journal of Hospitality \& Tourism Management. Vol. 5, No. 1, 2021, pp. 21-26. doi: 10.11648/j.ijhtm.20210501.14

Received: April 16, 2021; Accepted: May 5, 2021; Published: May 27, 2021

\begin{abstract}
The situation Peru is facing with the global COVID-19 pandemic and the economic recession during this 2020 constitutes the worst crisis over the last 100 years. This economic recession has not happened since the crisis of 1980. GPD may decline by $15 \%$ this year. Also, the perspective on global economy is terrible and a sharp contraction of global GDP is expected. On the other hand, the period between 2020 and 2021 will be considered as years of economic development lost. Specifically, receptive tourism in Peru is in danger of extinction because of the pandemic. Activity in the tourism market, which gives employment to 1.4 million people who are mainly women, is in total collapse. This article aims to make a proposal to help tourism sales recover their position as the most important section of service exports in Peru. The proposal is intended to encourage a non-traditional form of tourism in the tropical coast of the north of the country that should complement the traditional archeological tourism. The conclusions make emphasis on the fact that, at present, Peru is not exploiting its historical richness or using its comparative advantage in tourism, which could become a leading sector of domestic economy. Finally, our thesis is based on the notion that, from 2021 onwards, the recovery of the Peruvian economy must necessarily be based on exploiting the recovery of external demand rather than putting our trust in domestic demand growth.
\end{abstract}

Keywords: International Trade, Tourism, Peruvian Economy

\section{Introduction}

The situation in which we now find ourselves in Peru during 2020, which is in the midst of a mayor global epidemic and a global economic recession, is the worst social and economic crisis over the last 100 years. GDP may report an estimated annual decline by around $15 \%$ in 2020 [9]. Other experts' estimates vary from $12 \%$ to $20 \%$.

These levels of economic recession have not occurred in Peru since the economic crisis in the 1980s [3]. Neither the 1998-1999 recession nor the 2008-2009 slowdown have faced a crisis of such magnitude.

During the crisis of Alan Garcia's first government, despite an inflation rate that reached two million percent [3], the reduction in GDP did not go to these extremes. According to the aforementioned author: "In the last three years of the decade, there has been a fall of more than $20 \%$ of the product" [3]. This is equivalent to an annual decrease of $6.5 \%$. Compared to this, Covid-19 crisis may reach an annual decline by around $15 \%$ in 2020 .

The recessionary period 1998-999 in Fujimori's Government did not reach double-digit GDP declines. Actually, GDP fell by $8.8 \%$ in 1998 . The global financial crisis of 2007-2008 in Alan Garcia's second government led to a stagnation in the economy which grew by only $1 \%$.

The COVID-19 pandemic has already generated recession in the G20 countries. The Economist Intelligence Unit has reviewed its growth forecast for all countries globally, starting from the coronavirus pandemic. The results point to a very serious situation. The G20 group of developed countries will record a recession this year. The global economy will contract by about $2.5 \%$.

The crisis poses an unprecedented risk to Latin American economies since the coronavirus has created a supplydemand shock on at par with a global financial collapse. The direct economic impact will be great. In particular, this will 
cause a serious damage to Peruvian exports. How will COVID-19 impact Latin America? Latin America's export value contracted $3.2 \%$ in the first quarter of 2020 compared to the same period in 2019. The contraction would be higher for Peru [8]. The cited report estimates a decline of $30 \%$ for year 2020.

Another clear impact of the Covid-19 epidemic is the reopening of the debt crisis in developing countries. Only facing the coronavirus pandemic will demand extraordinary fiscal efforts due to lower tax revenues and lower tax collection due to higher expenses on health and social assistance. Governments in all developed countries have confirmed large increases in public spending and therefore higher public debt in their fight against coronavirus, representing an enormous problem for the poorest countries like Peru. One conclusion is that increased debt would be better than the widespread destruction of productive capacity caused by the epidemic. In the end, the public debt of all developing countries will increase widely through year 2020 . Sovereign debt crises are a fact, the only question begins with: when and who. A report presented by the Economist Intelligence Unit [11] projects the impact on the increasing levels of public debt in emerging countries from Latin America and Asia and developed countries such as Italy and Spain.

In short, the perspective of the global economy is terrible in 2020. Due to the coronavirus pandemic, an acute contraction of the global output is expected to occur this year. It seems that 2020 and 2021 will be years of economic growth lost. Global GDP will not recover to pre-coronavirus levels at least until 2022. The additional risk is that a second wave of the pandemic may derail economic recovery again. Also, a delay in the development of a vaccine would also pose an additional risk. [6].

The special situation of receptive tourism, caused by direct effect of the pandemic, is as follows: Foreign tourism to our country is currently endangered. The World Travel \& Tourism Council estimates that, in the baseline scenario, foreign visitors travelling to Latin America will decline by $45 \%$ in 2020 [16]. Both formal and informal tourism industry in Peru used to generate $\$ 22$ billion, representing 9.7\% of GDP [5]. From March 15, 2020 and according to the Ministry of Trade and Tourism [7], the pandemic and health emergency reduced to naught the activity of this market that employs 1.4 million people who are mainly women.

All the facts presented in this introduction helped us to set the objectives of this article which aim to highlight and propose, as a stated purpose, that external sales of tourism services regain their position as the most important part of service exports in Peru. The negative evolution of total exports of goods and services in Peru during the present year urgently requires to look for alternatives for the generation of foreign exchange and employment. Alternative tourism projects like the one presented here must be closely linked to both economic revivals and positive export recovery in different regions of Peru.

\section{Evolution of Peruvian Exports}

Receptive tourism was the main area of international trade services in Peru before the pandemic; therefore, the comparison between its dynamics and the growth of total exports presented below is very important.

This study suggests that the impact on exports is the thorniest and most complex legacy that this pandemic is leaving to us. However, it should be noted that the fall or slowdown in external sales were occurring since the Humala and Kucynski governments. The economic variable was the one that fell the most during the five-year period of Humala's government, becoming an indicator that recovered very slowly over the course of the current government. This was the case of both types of external businesses, for both exports of goods and services, including international tourism in Peru.

The evolution and analysis of exports of goods and services is presented below. In both cases, the evolution of the indicators can be observed. The decline of the exports is the variable that best explains the economic slowdown in recent years. In 2012, 2013, and 2014, exports declined exponentially by $-2 \%,-9 \%$ and $-11 \%$, respectively. Exports continued plummeted downwards by $-19 \%$ in 2015, compared to the previous year. Exports dropped in all years of Humala's government (2012 - 2015). (Figure 1) [13].

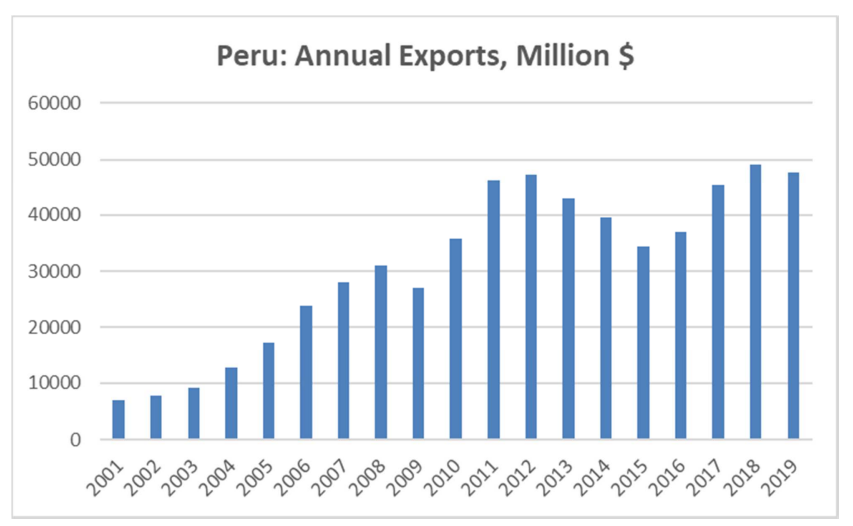

Figure 1. Peru's exports of goods during the period 2008-2019, Millions \$. Source: BCRP (2020) Weekly report.

The export debacle of those years is explained by the unfavorable international context of emerging economies. International prices for raw materials, especially metals, decreased during that period. In addition, the economic slowdown of China and the BRICS countries reduced the demand for Peruvian exports. The recurrence of the crisis in Europe and the United States was another reason for the negative impact of export behavior in that period. [13]. Finally, exports stagnated in 2016, recovered slightly from 2017 to 2018, and fell again in 2019.

Another indicator, and not less important, is the economic slowdown during the current millennium. The evolution of the GDP by sector of the economy shows two definitely different periods. There was a very favorable growth during the first period 2001-2013, but that dynamism slowed down 
during the second period 2014-2019. The average growth rate of the economy showed $6.8 \%$ annual average from 2001 to 2013 (excluding year 2009 as being an outlier observation). Unfortunately, the average growth rate was $3 \%$ per year during the period between 2014 and 2019. Our thesis is that export growth is the main determinant of the dynamics of the national GDP, but unfortunately, export growth weakened in the second period.

Besides the worrying situation of the deterioration of exports and poor economic growth during the last five years, which is very different from the period 2001-2013, we are also facing the serious crisis caused by Covid-19 in 2020.

As a preview of our further discussion, the eventual recovery will have to face the decreasing exports and the serious slowdown in GDP growth, designing a shock in exports and investments. However, we must keep in mind that the impact of higher exports on GDP will be immediate, while the impact on increased investment will take time to become effective.

In short, good export performance will be the most important variable that will reverse the decline in economic growth (from $6 \%$ to $2 \%$ ) that occurred between 2013 and 2019. The challenge consists on designing strategies to correct the decline of the exports and reach the highest export levels of the previous decade in the medium term.

\section{The Tourism Sector}

In this section we reviewed the recent development and analysis of services exports before the Covid-19 pandemic, with special emphasis on the tourism sector. It is a fact that the tourism business is the main area of service exports. This analysis includes both traditional archaeological tourism and non-traditional tourism.

According to the National Institute of Statistics and Informatics (INEI), more than 3.8 million tourists arrived to the country in 2015. If we take some data from 2002 when the flow of tourists was 1.06 million we can calculate an average growth of $11.3 \%$ per year, being a comforting situation. For the fourth consecutive time, Peru has also been chosen by the World Travel Awards as the best culinary destination in South America [14]. The evolution of the annual revenues in receptive tourism for recent years, using data from the Peruvian Foreign Trade Society, Comex, Peru [4] is presented in the following figure:

The above data also show that our tourism potential is being under-exploited. Although we have great comparative advantages for the development of this sector as well as twelve places listed by UNESCO as world heritage sites, the international tourist arrival is low. In 2015, more than 850 thousand people visited Machu Picchu, but the figure is less encouraging in the rest of the country. The most visited places were: Reserva Paracas, Nevado Huascaran, Manu and Nazca Lines. The places that received fewer visitors were: Tombs of the Lords of Sipan, Chavin de Huantár, Kuélap Walls, Caral, Rio Abiseo National Park, and ChanChan Citadel. It looks like we are sitting on a "gold bank" that we cannot exploit. [1]

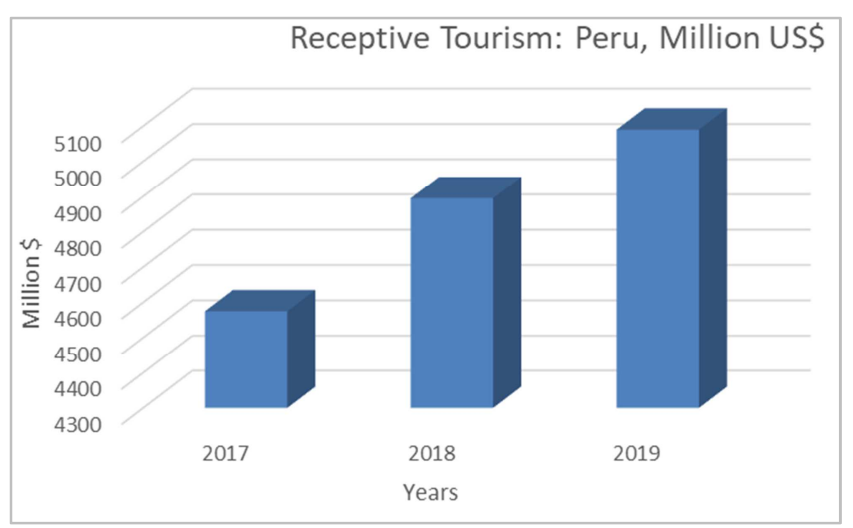

Figure 2. Receptive Tourism, Peru: Annual Sales.

However, other Latin American countries with lower historical and cultural heritage receive more visitors. In 2015, Brazil topped the list with 6.4 million tourists, followed by Argentina with 5.9 million visitors, and the Dominican Republic with 5.1 million [1]. Mexico, which has a preHispanic and colonial past similar to Peru, welcomed more than 29 million tourists in 2014. This allowed them to get tourism revenues that reached $\$ 16$ billion, compared to the $\$ 3$ billion reached by Peru [1].

But comparison with neighboring countries is more important. Ecuador receives 3 million foreign tourists annually, Colombia surpassed 4 million tourists annually, and Chile received 3.2 million visitors in 2014. The most probable explanation is that the Galapagos Islands in Ecuador and San Andres Island in Colombia are very important tourist destinations, as well as the Easter Island in Chile. It may seem that Peru would be missed of a resort island.

The corollary is that we are not fully exploiting our historical, geographical and biological wealth which is considered a waste of incomes in a substantial activity that has become the basis for the economy in many countries. Our great past can be the engine of a great future and an opportunity to energize regional economies with better hotel services and other tourist businesses.

A proposal for receptive tourism in Peru may include an adventure and relaxation tourism on tropical beaches as a complement to traditional archeological tourism, which may also require an island that can compete with the Caribbean islands.

Consequently, we recommend to analyze the inclusion of some ancient Guano islands of Peru as probable tourist destinations. Specifically, we suggest to start with the Lobos de Tierra tropical island, a guano island located off the coast of the Piura region. A project that includes the Lobos de Afuera Islands should also be considered because they are very close to the region. Lobos de Tierra island could become an ecological park that, respecting its current reality as a refuge for guano birds and sea lions, becomes a habitat of numerous species including, for example, tortoises similar to Galapagos tortoises. Moreover, Lobos de Tierra could be joined by nearby, current and artificial small islands to 
become a larger island, linking them with natural or artificial bridges similar to those that link the archipelago in the China Sea or Denmark.

This project would be complemented by a Decameron-like hotel built in front of the new Lobos de Tierra island. Tourists staying at this hotel could combine their stay in a heavenly beach with visits to the Lobos de Tierra ecological park through a paradise that shows them the natural resources of Peru. It would be accompanied by natural history museums and archaeological museums with a tourist attraction that receives visitors 365 days a year because of the tropical climate that exists at 5 degrees of south latitude in which those islands are located.

These Lobos de Tierra islands in Piura could be visited by tourist cruises with American, European and Asian visitors. Consequently, they could become the Peruvian "Galapagos Islands". The reviewed resort could compete with Cancun in Mexico or Varadero in Cuba.

In particular, cruise tourism will be considered safer after a Covid-19 vaccine is obtained. The expectations are that tourists from developed or emerging countries, either European or Asian, will prefer boat tourism over arriving by plane to Latin American cities that are considered risky and dangerous. The high informality of our countries, whether real or only perceived as such, offers no greater guarantees to tourists because they will continue with fear of Covid-19 contagion for a long period of time due to mutations in the virus, avoiding hotel accommodations and sightseeing in cities from exotic countries.

\section{The Tourism Project in Piura}

The key question is what capital resources the proposed project would develop with. It would definitely not be with public resources from the regional Government or Piura, but through Public-Private Partnerships that have been so successful international experiences.

Funding for tourism projects would be financially feasible through a Korean Consortium or Chinese Consortium protected by the FTA between Peru and those countries. If it came true, the project would offer the inhabitants of these Asian countries as well as American and European tourists a place to enjoy tropical holidays during the icy winters in the Northern Hemisphere.

An evaluation of The Tourism Project in the coastal area of the Piura region requires a first cost-benefit analysis of the proposed project. The hotel company would have to acquire the land on a beach of the vast coast of Piura, which is recognized by some experts as the "Peruvian Texas". The cost of building a 200-room with double bed hotel is estimated considering a construction cost, which at all costs, can be of $\$ 2000$ per square meter and a total roofed area of 5 thousand square meters. This would be a first module of a Decameron-like hotel.

To estimate the benefits of the project, cash-flows/incomes should be assumed for all days of the year (365 days) assuming full (100\% rooms) the whole year. Although this assumption is not real, the other not considered incomes such as restaurant, casino, shops, and other services) would compensate for not yet received incomes if, eventually, there are empty rooms. The allotted price is $\$ 100$ per day for a room.

The cost-benefit analysis with a 12-year time horizon is presented in the following table. The cost of the initial project or investment is $\$ 12$ million, annual sales are $\$ 7.3$ million, and full year net income is $\$ 2.92$ million. This represents $40 \%$ of sales and is interpreted as the company's EBITDA, which is the variable used in this type of real estate investment as a hotel. The final recovery value, with a flow at year 13 , is assumed to be the primal cost of building the property.

Table 1. Cost-Benefit Analysis of the Project.

\begin{tabular}{|c|c|c|c|c|c|c|c|c|c|c|c|c|c|c|c|}
\hline Variables & Year 0 & Year 1 & Year 2 & Year 3 & Year4 & Year 5 & Year 6 & Year 7 & Year8 & Year 9 & Year10 & Year11 & Year12 & Year13 & IRR \\
\hline Sales Flows & & 7.3 & 7.3 & 7.3 & 7.3 & 7.3 & 7.3 & 7.3 & 7.3 & 7.3 & 7.3 & 7.3 & 7.3 & 10 & \\
\hline $1-\operatorname{Cost}(\%)$ & & 0.4 & 0.4 & 0.4 & 0.4 & 0.4 & 0.4 & 0.4 & 0.4 & 0.4 & 0.4 & 0.4 & 0.4 & & \\
\hline Profit Flows & -12 & 2.92 & 2.92 & 2.92 & 2.92 & 2.92 & 2.92 & 2.92 & 2.92 & 2.92 & 2.92 & 2.92 & 2.92 & 10 & \\
\hline Discount Rate & Index & 1.237 & 1.530 & 1.893 & 2.341 & 2.896 & 3.583 & 4.432 & 5.482 & 6.782 & 8.389 & 10.38 & 12.84 & 15.88 & \\
\hline NPV, flows & & 2.361 & 1.908 & 1.543 & 1.247 & 1.008 & 0.815 & 0.659 & 0.533 & 0.431 & 0.348 & 0.281 & 0.227 & 0.630 & \\
\hline NPV, accumu & ation & 2.361 & 4.269 & 5.812 & 7.059 & 8.067 & 8.882 & 9.541 & 10.07 & 10.50 & 10.85 & 11.13 & 11.36 & 11.99 & \\
\hline IRR calculation & -12 & 2.92 & 2.92 & 2.92 & 2.92 & 2.92 & 2.92 & 2.92 & 2.92 & 2.92 & 2.92 & 2.92 & 2.92 & 10 & $24 \%$ \\
\hline
\end{tabular}

Source: Author's calculations. All monetary values are in million US dollars. Discount rate=IRR in this simulation.

The IRR of the project is estimated at $24 \%$, which is an acceptable result for this type of tourism project. In addition, the cost-benefit analysis should take into account the externalities generated by this type of tourism projects. A side effect of the Tourism-Piura project are the income multipliers that the project generates on the production and demand for goods and services in the Piura Region. A recent study presents these indicators, stating that the result of the analysis is that multipliers in service sectors such as Tourism are higher than industrial multipliers and even much higher than commodity multipliers in agriculture, fishing and mining. In addition, the study specifically states that Tourism ranks first in the sector ranking, with the highest level of income and employment multiplier. The income multiplier reported for the Tourism sector is equal to 1.93 [15].

The indicated results of the multiplier study in Peru means that the Tourism Project in Piura involves much larger social benefits than the returns to the investors who funded the initial project. Thus, this investment to promote tourism in Piura will result in higher employment levels, approximately 
the double compared to the direct jobs offered by the company that carried out the initial project.

This means that the Tourism-Piura pilot project has greater "social" benefits than the "private" benefits of the initial project. These social benefits are "externalities" of the project that are not considered in the analysis of the projects of companies. A theoretical discussion of externalities is presented in Mankiw [10] and Tietenberg [12].

A future extension of the study would be the development of a method for measuring the economic and social impacts of these externalities. The questions we need to ask ourselves are: how much would the benefits of the pilot project increase if social benefits or externalities are considered? How many points would the Internal Rate of Return of the project increase if the social benefits of the multiplier are considered?

This does not mean that the company needs to modify its project analysis. Technically, the company should continue to apply only private costs and private profits in the analysis. A government agency would be required to consider social benefits as well as other social costs. Other social costs could deal with the environmental damage of a tourism project. The social benefits would be the exceptional returns from a project which are reflected in its multiplier effects on employment, consumption and new investments which are generated in the regional economy where the tourism project is installed.

If a project generates greater social benefits than business benefits, economic incentives that increase such investments could be justified. This would not have to be direct subsidies to companies. These incentives could take place through new public investments that address deficiencies in regional infrastructure or in other areas. This will allow more companies to be attracted to invest in new tourism projects in the region.

The Net Present Value Formula can be used to make a social cost-benefit analysis of a tourism investment project. This NPV formula must be modified to include the additional social benefits and costs associated with the investment project.

\section{Economic Recovery}

The revival of the Peruvian economy must necessarily be based on meeting the revival of the external demand rather than counting the growth of domestic consumption. The argument is that the short-term projections of Peruvian growth are the lowest in the entire Latin American region and much lower than the projected growth for developed countries and for the world as a whole.

During the last two decades, Peru has followed a proexport economic model, timidly copying the fabulous Chinese model with excellent results. This is reflected in the strong growth of Peruvian exports over the past twenty years, already discussed in this article. Today, Peru exports some products that we did not even know, as in the case of blueberries.

Since the origin of post-Covid-19 demand will be the international market, this exporting model should not be changed. The world will continue to demand raw materials and exotic natural foods such as avocado, mango and blueberries. We are sure that most Peruvian economists, from every political orientation, will not agree with the objective of underlying the current Peruvian export model -twin brother of the Chinese model- which favors small exporting companies in the agricultural sector in the Coast and Sierra regions of Peru, generating both indirect employment and so many multiplier effects.

Unquestionably, the model must be improved. It is true that inequalities must decrease in such a way that we do not reflect ourselves in the Chilean mirror. The wage earners should also obtain benefits and extreme poverty should be eliminated forever. But eliminating the export model would reduce to zero the incomes of the current modern agriculture and registered mining.

Undoubtedly, this export model explains the miracle of the colossal economic growth of the People's Republic of China in recent decades. China was ranked among the last countries, listed in the level of GDP per capita and absolute GDP, among the poorest countries in Asia and sub-Saharan Africa. This used to happen about forty years ago.

The economic miracle of the People's Republic of China, which can be found in the books of history, will be studied by the young generations of the next thousand years. Since it is the greatest economic miracle in history, it is considered the first economic power on the planet at present. Never before in human history has a country made an economic leap in the scale of the Chinese miracle.

The statue of Deng Xiao Ping, the architect of modern China's economic reforms, is displayed in Shenzhen City. This city is part of a technology cluster along with Guangdong-Hong Kong-Macau- Greater Bay Area, the largest technology cluster on the planet. It is a metropolis of 70 million people that manufactures $90 \%$ of the electronics on the planet and accounts for $25 \%$ of China's exports [17]. The Chinese are not afraid of robotization because they will manufacture robots for European, American, Asian and other industries around the world.

Finally, the export shock should include macro-level measures such as: maintaining export competitiveness by allowing an increase in the exchange rate in line with market forces and domestic inflation, a broad public-private agreement to promote exports and repowering trade offices in all countries that have negotiated an FTA with Peru. Sectoral policy measures are also important. They include: eliminating red tape to authorize agricultural and agroindustrial exports, improving port access infrastructure and port management efficiency, and maintaining the drawback system for non-traditional exports [13].

\section{Conclusions}

The outlook for the global and national economy is terrible in 2020. Due to the coronavirus pandemic, a sharp contraction in domestic production is expected in 2020 and 2021, which will be lost years of economic growth. GDP will 
not recover to pre-coronavirus levels until at least 2022. The additional risk is that a second wave of the pandemic may derail the economic recovery again. A delay in the development of a vaccine would also pose an additional risk.

Receptive tourism by direct effect of the pandemic and the health emergency has reduced its market activity in Peru, which employs 1.4 million people, predominantly female labor.

Our thesis is that export growth is the main determinant of the dynamics of Peru's GDP and unfortunately, export growth weakened leading to poor economic growth for the last five years, a very different situation from the period 2001-2013. But the very serious covid-19 crisis came "to put salt in the wound" or rather "add insult to injury" of our low growth. Only a revival of exports will reverse the decline in economic growth, as expectations of a significant recovery in domestic demand are close to zero.

Another conclusion is that we are not fully exploiting our historical, geographical and biological wealth; also, tourist activity, which can become an engine of economic growth, is being wasted. Our great past can be the engine of a great future and an opportunity to energize regional economies with better hotel services and other tourist businesses.

The solution for Peruvian receptive tourism can be a relaxing tourism on tropical beaches, complementing traditional archaeological tourism. Possibly, an island that can compete with the Caribbean islands is required. Therefore, we propose to value some of Peru's ancient guano islands, such as the Lobos de Tierra tropical island and the Lobos de Afuera islands, a set of islands located off the coast of the tropical Piura region. The cost-benefit analysis of the project presented here gave optimistic results.

Finally, we insist on the thesis that the revival of the Peruvian economy must necessarily be based on meeting the revival of external demand, instead of relying on the growth of domestic consumption. Again, Peru's growth projections are the lowest in Latin America and lower than the projected growth for the world as a whole.

\section{References}

[1] Arroyo J. (2015) "Motor sin aprovechar" ("Non-exploited Engine"), El Comercio, 26 November, 2015.
[2] Banco Central de Reserva del Perú (2020) Nota Semanal. Recuperado de www.bcrp.org.pe el 20-06-2020.

[3] Boloña, C. (1993). Cambio de Rumbo. Quinta edición. [ de Economía de Libre Mercado. Lima: SIL.

[4] Canatur (2019). Turismo generó divisas al Perú por US\$4,895 millones en 2018, Portalturismo / 3 abril 2019. https://portaldeturismo.pe/seccion/estadisticas.

[5] Canatur (2020) Aviso: Nuestro Turismo Agoniza. Diario El Comercio, 15-06-2020, página 5.

[6] Economist Intelligence Unit (2020). Special Report: Sovereign debt crises are coming. http://pages.eiu.com/SubsMagmt.html

[7] El Comercio (2020) El Golpe Económico del COVID-19. Edición del 25-06-2020, página 11.

[8] IDB-INTAL (2020) How Covid-19 is impacting Foreign Trade in LAC. Newsletter\#5, www.iadb.org

[9] IPE (2020) Economía peruana caería a dos dígitos este 2020 por COVID-19. Diario El Comercio, 30-05-2020.

[10] Mankiw N. (2014). Principles of Economics. Mexico DF: Cengage Learning, South-Western.

[11] The Economist (2020) Covid-19 to send almost all G20 countries into recession. EIU, 27-03-2020.

[12] Tietenberg T. (1992) Environmental and Natural Resource Economics. New York: Harper Collins Publishers.

[13] Torres Zorrilla J. (2015) "Un shock de exportaciones para la economía peruana”, El Comercio, 4 Noviembre, 2015.

[14] Torres-Zorrilla J. (2016). Shock de Exportaciones y mayor Impulso al Turismo. Revista Strategia, Edición Internacional, Año 10, No 41, Centrum Publishing.

[15] Torres-Zorrilla J., (2019). Production and Sector Multipliers in Peru: A comparison with Other Latin American countries. IBIMA 34th Conference Proceedings. Madrid, Spain

[16] WTTC (2020) Latin America Scenarios 2020 \& Economic Impact from Covid-19. www.wttc.org, recuperado el 22-062020.

[17] Wikipedia (2020). Zonas Económicas Especiales: China. Recuperado el 22-06-2020 de: https://es.m.wikipedia.org/wiki/Zonas_economicas_especiales de China. 